Article

\title{
Study on the Possibilities of Natural Use of Ash Granulate Obtained from the Combustion of Pellets from Plant Biomass
}

\author{
Andrzej Greinert ${ }^{1, * \mathbb{C}}$, Maria Mrówczyńska ${ }^{2}$ and Wojciech Szefner ${ }^{3}$ \\ 1 Institute of Environmental Engineering, University of Zielona Góra, 65-615 Zielona Góra, Poland \\ 2 Institute of Civil Engineering, University of Zielona Góra, 65-516 Zielona Góra, Poland \\ 3 Lubuski Centre for Innovation and Agricultural Implementation Ltd., University of Zielona Gora, Co., \\ 66-100 Sulechów, Poland \\ * Correspondence: A.Greinert@iis.uz.zgora.pl
}

Received: 16 April 2019; Accepted: 28 June 2019; Published: 3 July 2019

\begin{abstract}
As a step towards the diversification of electricity and heat sources, the EU countries suggest the use of biomass. The combustion of biomass poses the problem of the use of ash produced in the process. There are fluctuations in the properties of energetic biomass, which results in high variability of ash obtained by combustion, especially in terms of specific conductivity (EC) $\left(8.1-9.7 \mathrm{mS} \cdot \mathrm{cm}^{-1}\right)$, the total content of components and their bioavailability. The combustion of biomass leads to large fluctuations in the total content of carbon in the ash (13.6\%-28.6\%). In this way, waste material with very different biological properties and cation exchange capacity is obtained. Ash from the combustion of biomass is an alkalizing material, rich in $\mathrm{Ca}, \mathrm{K}$ and $\mathrm{Mg}$ carbonates (4.5\%). The high average bioavailability of $\mathrm{Pb}(87.4 \%), \mathrm{Cd}(63.1 \%)$ and $\mathrm{Zn}(46.9 \%)$ present in the ash is an environmental problem. The mobility of these heavy metals was reduced by half by the addition of bentonite during the process of ash granulation. With high doses of ash ( $4.4 \%$ of the mass of substrate), there is a significant bioaccumulation of $\mathrm{Cd}$ in the roots of Begonia semperflorens and Thuja occidentalis $\left(1.0-3.8 \mathrm{mg} \cdot \mathrm{kg}^{-1}\right)$. Another disturbing issue is that during the cultivation of these plants, $\mathrm{Cr}$ is bioaccumulated in the roots $\left(0.5-3.8 \mathrm{mg} \cdot \mathrm{kg}^{-1}\right)$.
\end{abstract}

Keywords: combustion of biomass pellets; use of ash; ash granulation

\section{Introduction}

The production of energy from biomass has become more and more common recently, especially in the form of co-combustion with coal [1,2]. The share of biomass in the production of energy from renewable energy sources in Poland is increasing [3,4]. During the combustion of biomass, a significant amount of fly ash and bottom ash is produced, which may be a significant environmental challenge $[5,6]$ as well as a problem for boilers [7-10]. These materials have waste-codes 1001 01-03, 10 01 14-17 and 1901 11-16 [11] and are subject to further treatment or management. The amount and properties of the resulting bottom ash depend on the combustion system type, type of biomass, and in the case of plant biomass also on plant species, cultivation technology, including fertilization methods, soil properties and even external conditions during cultivation.

The amount of ash produced from biomass is described as dependent on the origin of the material. This is within $0.4-1.8 \%$ for pure wood, $6.3-10.4 \%$ for wood bark, $2.4-7.7 \%$ for energy crops, 6.9-9.2\% for agricultural biomass and $1.1-9.2 \%$ for waste from the production of plant-based food [12]. Falemara et al. [13] obtained an amount of ash between 3.4-4.9\% for briquette from peanut shells, maize cobs and Anogeissus leiocarpus. James et al. [6] found that the typical amount of ash produced was 1.2\% for pine wood, $1.0 \%$ for willow wood, $0.8 \%$ for birch wood, $12.9 \%$ for Miscanthus, which was much 
greater, $9.3 \%$ for rice pellets, $16.3 \%$ for rice husks and $5-10 \%$ for agricultural crop materials. A large amount of ash is also produced from tree bark (3-4\%) and contaminated bark (5-15\%). However, not all sources mention that such a large amount of ash is produced, e.g., information can be found that for Miscanthus this index is only 2-3.5\% [14].

According to the study by Huinink [15], it is important to correctly prepare a substrate for bedding plants using different materials and fertilizers. Ash contains significant amounts of plant nutrients, mainly P, K, Ca, Mg [1,2,16-18] and some microelements- $\mathrm{Cu}[12,16,19], \mathrm{Zn}[16,19,20]$, which requires thought about its use as fertilizer in horticulture, agriculture and forestry $[14,16,20,21]$. The use of ash as fertilizer is ecologically desirable because in this way ingredients taken from soil by plants return to it [12]. The properties of ash significantly influence the choice of final use. After burning wood biomass Gibczyńska et al. [20] obtained ash with the following grain-size composition: $32 \%$ sand, $41 \%$ silt and 27\% clay. Antonkiewicz and Pełka [19] described the ash used as sandy loam (62\% sand, $35 \%$ silt and 3\% clay), which is closer to the one described here. Lanzerstorfer [14] pointed out that after burning miscanthus at about $600{ }^{\circ} \mathrm{C}$, the ash obtained had a $6.5 \%$ content of particles $<1.9 \mu \mathrm{m}$ in the total mass. This fraction was supplemented with $33.8 \%$ of material that was within the range of 5.2-27 $\mu \mathrm{m}$ and $49.7 \%$ above $76 \mu \mathrm{m}$.

Ash has a high neutralizing potential, which means that it can be regarded as a substitute for fertilizer lime, especially in reclamation [22]. This type of research is not yet well documented in relation to ash produced during the combustion of biomass. Most authors focus on using bottom ash and fly ash from the combustion of lignite in coal-fired power plants as a substitute for lime fertilizer. In each of these cases, the high content of calcium compounds $[2,6,16,17,23-26]$ and the high values of $\mathrm{pH}$ of ash (in the range of 10-12 [16,25]) indicates the correctness of such form of use. In the context of soil reclamation processes and construction activities (in civil engineering) as well, it is often mentioned that there are possibilities of using ash for improving sorption properties, stabilization of swelling soils and, if it has good strength characteristics, also as an aggregate substitute [22,27-30]. Ashes from the combustion of organic matter have sorption properties because of their relatively large specific area. The sorption of $\mathrm{Pb}$ (II), $\mathrm{Zn}$ (II) and Cr (III) ions in this respect was demonstrated by Papandreou et al. [31]. As regards the reclamation of post-mining land, references are available on the methods for preventing oxidation of pyrites through sealing soil with bottom or fly ashes [22,32-34].

Sometimes ideas based on advanced processing are also mentioned. They are aimed at producing clean mineral fertilizers from ash, e.g., potassium [14]. Waste from the combustion of plant biomass - both of agricultural and forest origin—is usually not very polluted, especially not by heavy metals $[6,20]$. The situation is completely different in the case of the combustion of solid waste of various origin, including hazardous waste, where the total content of trace elements can be counted in thousands of $\mathrm{mg} \cdot \mathrm{kg}^{-1}$ [35]. Some publications also mention another use-addition to cement. It is possible because of the pozzolans presence in ashes-a class of siliceous or siliceous and aluminous no cementitious materials. The pozzolanic reaction influences the cement strength depending on the material's pozzolanic activity. The main reaction product of the pozzolanic reaction are calcium silicate hydrate phases [36,37]. Outside land construction, ashes are used for the production of geopolymer concrete with good parameters for their use in marine construction [38]. In the face of various cement types produced with the participation of ashes, advanced research is carried out to further improve their strength using nanotechnology [39] and graphene technology [40].

The aim of the study was to check whether it was possible to safely use ash from biomass pellets in the cultivation of ornamental plants. Questions were asked whether ash had any properties improving the characteristics of soils and greenhouse substrates, and whether it was ecologically safe to use ash as fertilizer. In terms of the ecological safety of using ash for agricultural purposes, the aim was to analyse ash behaviour in the soil or substrate-plant system. In the course of the research, the ash behaviour was analysed after a specific pre-preparation procedure. Ash was granulated to obtain the effect of its prolonged action in the soil or substrate and to reduce the short-time effect of environmental response on fertilization. Although ornamental plants from urban green areas are not likely to enter the food 
chain, their chemical properties have a significant impact on the quality of compost produced from plant waste.

\section{Materials and Methods}

\subsection{Biomass Preparation and Analysis}

The biomass intended for combustion was prepared in the form of pellets with a diameter of $8 \mathrm{~mm}$, produced by "PAL-BUD" Marian Serwach Pellet Plant in Chlebowo. The material subjected to pelletization consisted of $80 \%$ straw and $20 \%$ willow wood. The straw used for the production of pellets came from rye (Secale cereale L.) grown on the surrounding sandy soils with low bonitation. The rye straw was a mixture composed from the most frequently cultivated cultivars: SU Stakkato, Dańkowskie Amber, Stanko, Brasetto and SU Drive. The basket willow, known as the common osier also (Salix viminalis L.) is grown in a marshy wastelands. Flexible shoots (called withies) are collected annually using special combine harvesters. The willow withies were a mixture composed from cultivars: Inger, Sprint, Start, Tora, Tordis and Turbo. The producer does not collect the detail information about the share of the following cultivars in a mixture. The biomass pellet was made of local products, which after harvesting and transport to the factory were ground in a stationary grinder to form sawdust. The sawdust was dried in a tumble dryer. To increase the compaction effect and to obtain a surface with greater smoothness, the rapeseed pressings were added to the components in the amount of $10 \mathrm{~kg}$ per 1 ton of sawdust. Directly before input of the material to the pelleting machine, it was treated with steam in the evaporator to achieve the effect of surface moisturising. Pellets were analysed for chemical composition at BTU Cottbus, Lehhrstuhl Kraftwerkstechnik (KWT). The level of moisture and the content of ash and other selected components were determined using the standard procedure for elemental analysis, and the total content of selected macro- and microelements was determined by X-ray fluorescence (XRF, Niton XL3t 900, Thermo Fisher Scientific, Waltham, MA, USA) analysis after the samples were incinerated $[10,12,14]$. The biomass pellets from Chlebowo were combusted in a prototype FORST boiler equipped with two burners: $24 \mathrm{~kW}$ and $48 \mathrm{~kW}$ (Forster Heizkessel, PE40, Forster Heiztechnik GmbH, Forst, Lausitz, Germany) adapted for combusting biomass, with an automatic pellet feeding and ash removal system. The main combustion parameters were: incineration temperature $800^{\circ} \mathrm{C}$, air flow $20 \mathrm{~m}^{3} \cdot \mathrm{h}^{-1}$, mass fuel consumed $1.5 \mathrm{~kg} \cdot \mathrm{h}^{-1}$, exhaust gas temperature $141-162{ }^{\circ} \mathrm{C}$, exhaust gas mass flow $30 \mathrm{~g} \cdot \mathrm{s}^{-1}, \mathrm{O}_{2}$ in exhaust gas $11-14 \%$, maximum operating temperature $90^{\circ} \mathrm{C}$, maximum operating pressure 2.5 bar, pellet calorific value $17.73 \mathrm{MJ} \cdot \mathrm{kg}^{-1}$, pellet residual moisture $8-9 \%$ and ash production $3.84 \%$ of the pellet mass.

\subsection{Preparation of Granulate from Ash}

The granulate was prepared from ash obtained by combustion of biomass pellets (Figure 1). Granulation was carried out by mechanical "coating" with different proportions of a bentonite mixture as an agent strengthening the structure of the material. The following mixtures were used in the tests:

- pure ash,

- $955 \mathrm{~g}$ ash $+45 \mathrm{~g}$ bentonite,

- $910 \mathrm{~g}$ ash $+90 \mathrm{~g}$ bentonite,

- $\quad 775 \mathrm{~g}$ ash $+225 \mathrm{~g}$ bentonite.

Each of the variants was repeated five times. The variants without the addition of bentonite and with the addition of $45 \mathrm{~g}$ and $90 \mathrm{~g}$ of bentonite to $955 \mathrm{~g}$ and $910 \mathrm{~g}$ of ash, respectively, were unstable, and the granulate was very easy to crush. For this reason, after the analysis of the preliminary test results, granulate from a mixture of $775 \mathrm{~g}$ ash $+225 \mathrm{~g}$ bentonite was chosen for vegetative tests. This mixture also had good properties when the stability of the granulate was tested in water and its impact on changes in the $\mathrm{pH}$ of the water. There are studies suggesting the possibility of obtaining durable 
ash granulate/pellets that could be used even in the aquatic environment [31] but for that purpose materials of different origin are required.
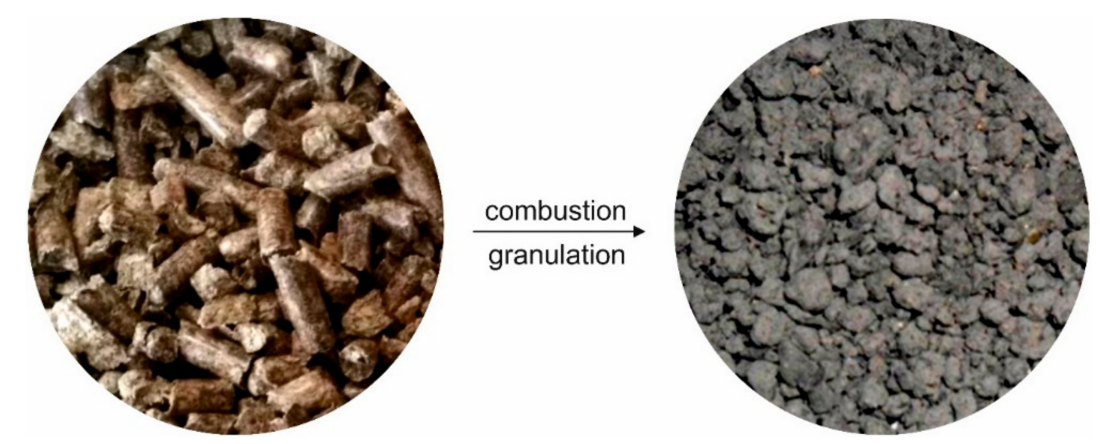

Figure 1. Biomass pellet and the granulate produced from the bottom ash after biomass combustion (775 g ash $+225 \mathrm{~g}$ bentonite).

\subsection{Studies on the Possible Use of Ash}

An experiment aimed at verifying the possibility of using ash from the combustion of biomass as a soil improver was carried out at the Lubusz Centre of Innovation and Agrotechnical Implementations (LCIAI) of the University of Zielona Góra. The facility is located in the Republic of Poland, in the Lubusz Voivodship, at a geographical location of $52^{\circ} 8^{\prime} 3.39^{\prime \prime} \mathrm{N}, 15^{\circ} 35^{\prime} 22.36^{\prime}$ E. The experiment included both testing pellets from ash and bentonite as a substrate component, as well as a biological test based on the analysis of the effect of the addition of granulate on higher plants-Pelargonium $x$ hortorum L.H. Bailey, the variety "Salomon Pink", Begonia semperflorens cult. hort. the variety "Olimpia" and Thuja occidentalis L.

Two facilities were used in the experiments:

- a Venlo type greenhouse; cultivation in pots on mobile tables; the building is equipped with a climate computer made by the company Synopta (TANAKE, Warsaw, Poland), HortiMax (Hortisystems, Pulborough, West Sussex, England), MultiMa (TANAKE, Warsaw, Poland), using the following parameters: precipitation, radiation intensity, wind speed, temperature outside and inside the greenhouse, humidity for controlling the mechanisms of the greenhouse;

- a cultivated field located in the Centre, near plastic tents; cultivation in soil-Brunic Arenosols (Aric), according to the World reference base for soil resources 2014, update 2015.

The experiment was carried out in random blocks, in two parallel experimental facilities-in a greenhouse (the pot experiment) and in a field (in soil)-Table 1. The following combinations were prepared to investigate the properties of ash as an improver of greenhouse substrates:

- $450 \mathrm{~g}$ substrate without ash (A);

- $440 \mathrm{~g}$ substrate $+10 \mathrm{~g}$ ash granulate (B); ash share in the mixture: $2.22 \%$;

- $430 \mathrm{~g}$ substrate $+20 \mathrm{~g}$ ash granulate $(\mathrm{C})$; ash share in the mixture: $4.44 \%$;

- $420 \mathrm{~g}$ substrate $+30 \mathrm{~g}$ ash granulate (D); ash share in the mixture: $6.66 \%$.

The plants were grown on optimum substrates for individual species, modified by the addition of ash granulate in the greenhouses (as it has been described above) and by the addition of analogous amounts of ash granulate in the fields that represented dosages of $250 \mathrm{~kg}$, $500 \mathrm{~kg}$ and $750 \mathrm{~kg}$ per $1 \mathrm{ha}$ respectively. These are relatively small admixtures reflecting the tendency to manage ash in accordance with the idea of sustainable development. In other studies, significantly higher doses were tested, in the range of 1.5-4.5 tons per 1 ha, but they were used for industrial plants [16].

Ash was added to the substrates prepared for the begonias and the pelargoniums from a mixture of high and low peat limed to a $\mathrm{pH}$ of 6.5 , and for the thujas from a mixture of high and low peat with 
a $\mathrm{pH}$ of 5.0. In the field pot-size holes were made for each plant, the plants were planted, and the holes were covered with clean soil or a mixture of soil with $10 \mathrm{~g}, 20 \mathrm{~g}$ or $30 \mathrm{~g}$ ash granulate. With an analogous dose per 1 ha this would be an application of $250 \mathrm{~kg}, 500 \mathrm{~kg}$ and $750 \mathrm{~kg}$ ash granulate, respectively. Each combination was repeated three times.

Table 1. Experiment scheme.

\begin{tabular}{ccc}
\hline Substrate Composition & Plant Used in the Experiment & Combination Code \\
\hline A; base substrate (control) & R1 & AR1 \\
B; substrate + 10 g ash granulate & Pelargonium x hortorum & BR1 \\
C; substrate + 20 g ash granulate & L. H. Bailey “Salomon Pink”) & CR1 \\
D; substrate + 30 g ash granulate & DR1 \\
\hline A; base substrate (control) & R2 & AR2 \\
B; substrate + 10 g ash granulate & Begonia semperflorens cult. hort. & BR2 \\
C; substrate +20 g ash granulate & "Olimpia” & CR2 \\
D; substrate +30 g ash granulate & & DR2 \\
\hline A; base substrate (control) & R3 & AR3 \\
B; substrate +10 g ash granulate & BR3 \\
C; substrate +20 g ash granulate & Thuja occidentalis L. & CR3 \\
D; substrate +30 g ash granulate & & DR3 \\
\hline
\end{tabular}

In total, 108 plants of three species were planted in the first year of the study, 12 in the field and 24 in the greenhouse. In the greenhouse, the pots were placed in a way that eliminated the possibility of blocking the sunlight for one plant by the other. In the field, the plants were planted at a spacing of $0.6 \times 0.7 \mathrm{~m}\left(0.42 \mathrm{~m}^{2}\right.$ per 1 plant), which eliminated the impact of individual plants on each other. Moreover, there were lanes separating the individual combinations. Complete records were kept of the activities carried out during the experiment and of the basic atmospheric conditions that had an impact on plant growth and development. Every four days the parameters of the weather conditions were recorded: precipitation, insolation intensity, wind speed, temperature outside and inside the greenhouse and humidity in the greenhouse. The lack of moisture in soil and substrate was supplemented by irrigation, with the amounts of water collected in Figure 2a,b.

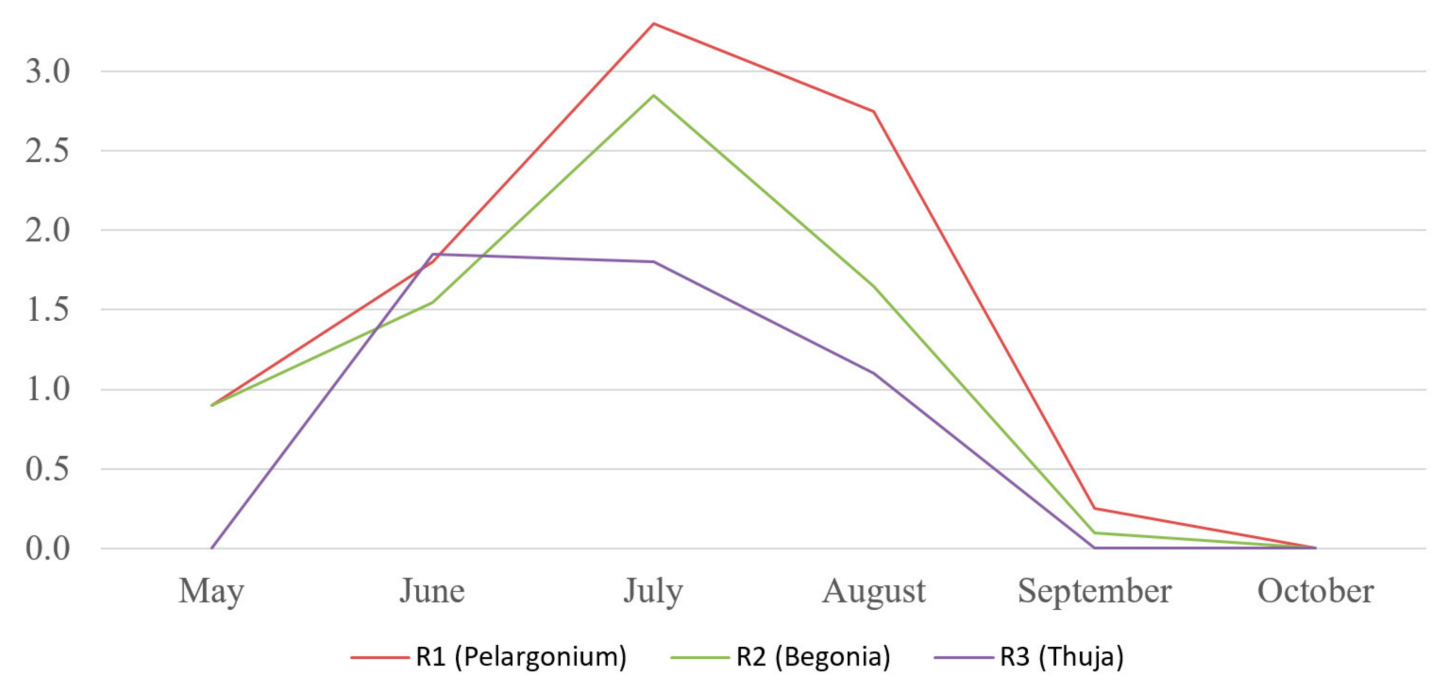

(a)

Figure 2. Cont. 


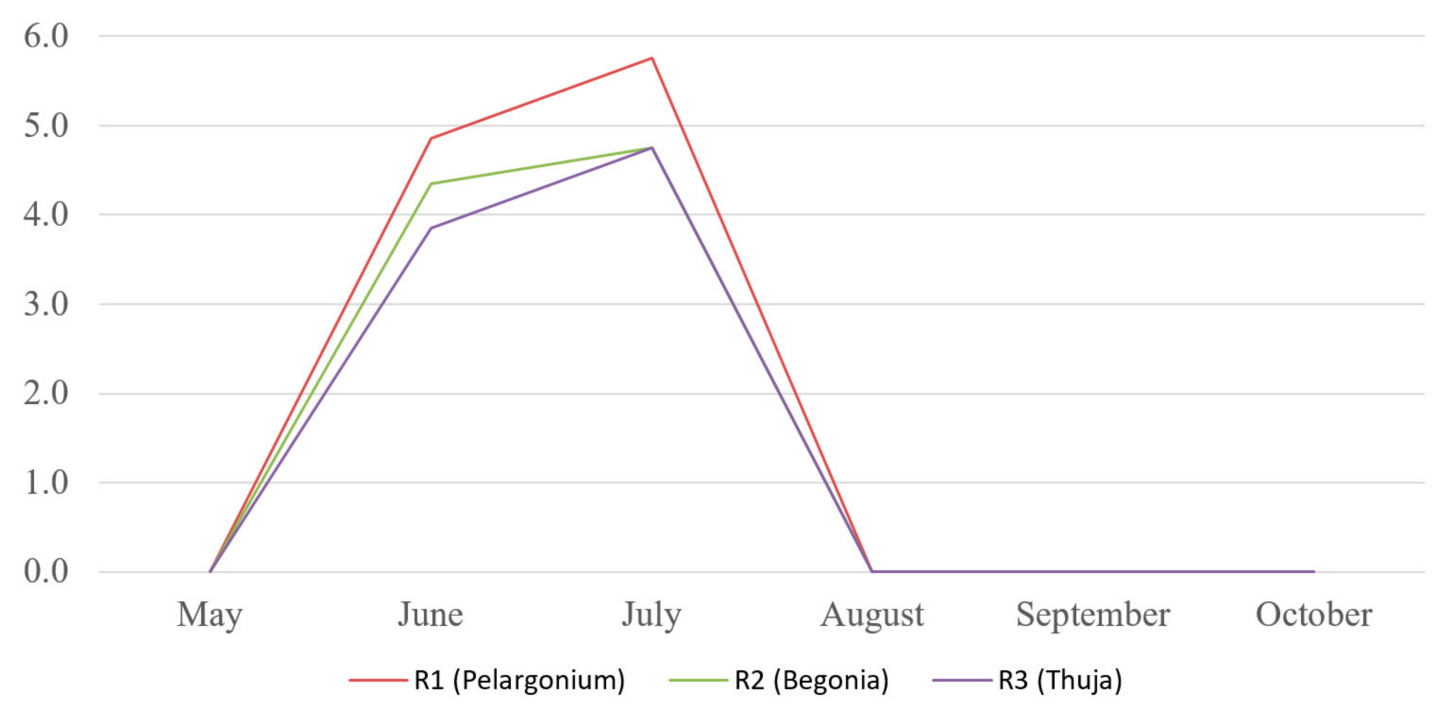

(b)

Figure 2. Irrigation of plants in the months of the experiment, (a) in greenhouse, (b) in field.

During the experiment, the maximum temperature in the greenhouse ranged from $27^{\circ} \mathrm{C}$ to $43^{\circ} \mathrm{C}$, and in field conditions from $20^{\circ} \mathrm{C}$ to $34^{\circ} \mathrm{C}$. The minimum temperature in greenhouse conditions was in the range of $0.5-12{ }^{\circ} \mathrm{C}$ and in the field of $9-18^{\circ} \mathrm{C}$. The highest temperatures were recorded in August, and the lowest in October.

Photographic records were also kept, and the amount of water delivered to each plant was recorded. Samples of biological material were systematically taken from the above-ground parts of the test plants. The study presents the results of sampling at the end of the experiment-after a full vegetation cycle-21-23 October.

\subsection{Methodology of Laboratory Analyses}

All laboratory analyses at the LCIAI were carried out in accordance with the standardized analytical procedures described in standards and scientific specifications for non-standardized analyses:

- Grain-size composition was determined using the sieve method and the hydrometric method, as specified in the description of the Polish Society of Soil Science, Classification of the granulation of soils and mineral structures, from 2008;

- $\quad \mathrm{pH}$ was determined potentiometrically in a mixture of air-dry solid material: water 1:5, using an InoLab pH meter equipped with a WTW SenTix 41 glass electrode (Xylem Analytics, Weilheim Germany);

- total carbon content (TC), inorganic carbon content (IC) and total organic carbon content (TOC)—using the Pregla-Dumas method-dry samples were combusted in a pure oxygen environment and the resulting exhaust gases were automatically measured using a CHNS/O 2400 Series II PerkinElmer elemental analyser (PerkinElmer Inc., Baesweiler, Germany). The measurements were conducted for weights of $1.5-2.5 \mathrm{mg}$ in three repetitions, from which the mean and standard deviations were calculated;

- specific conductivity (EC) was determined conductometrically in mixture of air-dry solid material:water 1:5; using a Eutech Instruments Cyberscan PC300 (Thermo Fisher Scientific Inc., Waltham, MA, USA) and an Elmetron CPC-411 with an EC-60 conductivity sensor (Elmetron, Zabrze, Poland);

- carbonate content was determined using a standardized method consistent with ISO 10693;

- subtotal content of selected components was determined after the dissolution of hot substrate samples (in a Perkin Elmer MPS microwave oven) in a mixture of hydrochloric and nitric 
acids (Aqua regia), using the ICP-OES method (Perkin Elmer Optima 8000)—ISO 11466 (1995); simultaneously, in the Perkin Elmer laboratory, pure materials—bentonite and ash were analysed for comparison;

- potential availability of components for plants in acidic substrate were analysed in an extract of $0.1 \mathrm{M} \mathrm{HCl}$. The extract was prepared as cold by mixing a sample of the substrate with an extractor for $1 \mathrm{~h}$ in a soil mixer. The analysis was carried out using the ICP-OES method (Perkin Elmer Optima 8000) by Page et al. [41].

Each sample was pre-homogenised to eliminate the element of randomness. This was done by mixing the material intended for analysis mechanically. Each test was repeated three times.

\subsection{Analysis of the Results}

The results of the study were subjected to statistical analysis including the calculation of basic statistics, correlations between factors and variance analysis. This was done using the procedures of the software Statsoft Statistica 13.1. The results were analysed using multiple regression to present the quantitative relations between the independent variables (the explanatory ones) and the dependent variable (the one that is being explained). It should be emphasized that regression techniques make it possible to determine the existence of relations between variables, but they do not make it possible to prove the existence of a cause and effect relation that is the basis of these relations. In these analyses, the independent variables were the amounts of selected elements $(\mathrm{Ca}, \mathrm{Cd}, \mathrm{Cu}, \mathrm{Cr}, \mathrm{K}, \mathrm{Ni}, \mathrm{Mg})$ in the base substrate, and the dependent variables were the amounts of these elements in the plant biomass (Pelargonium $x$ hortorum L. H. Bailey "Salomon Pink", Begonia semperflorens cult. hort. "Olimpia" and Thuja occidentalis L.). The analyses were carried out separately for the greenhouse cultivation and for the field cultivation, and in both cases also for different types of plant biomass.

\section{Results and Discussion}

\subsection{Characteristics of Biomass Pellets}

The pellets subjected to analysis consisted of straw and willow wood in a proportion of $80 \%+20 \%$. The results reflected the use of such ingredients as pure wood, which produces a relatively small amount of ash and herbaceous plants, which produce a greater amount of ash. The content of $\mathrm{S}, \mathrm{N}$ and $\mathrm{Cl}$ in the biomass was low (Table 2).

Table 2. Selected characteristics of the biomass pellets (content of dry mass in \%).

\begin{tabular}{ccccccccc}
\hline Ash & $\mathbf{C}$ & $\mathbf{S}$ & $\mathbf{N}$ & $\mathbf{H}$ & $\mathbf{O}$ & $\mathbf{C l}$ & $\mathbf{K}$ & Ca \\
\hline 2.74 & 51.64 & 0.14 & 0.28 & 6.30 & 41.64 & 0.21 & 0.542 & 0.246 \\
\hline
\end{tabular}

The amount of ash produced from biomass was higher than noted in wood, but lower in comparison to agricultural crops. This situation can be related to the quality and origin of the material [13,42]. In the experiment the pellet made of wood without the bark and straw material was used. In the literature the relatively high ash production when the bark in burned material is presented [14]. In the pellets analysed the content of Ca and $\mathrm{K}$ was low, relatively to many literature descriptions [1,6,12-14,42]. The content of $\mathrm{Cl}$ was also lower than the values mentioned in the cited literature. However, it should be remembered that the content of components in biomass is to a large extent determined by the species composition as well as the type and amount of fertilizers used for the cultivation of energy plants. From this point of view, the differences in chemical composition are expected. 


\subsection{Analysis of Ash Properties}

The sieve analysis showed the presence of $1 / 6$ of skeleton material with a diameter larger than $2 \mathrm{~mm}$ in the ash mass. In ash particles smaller than $2 \mathrm{~mm}$, the predominant presence of the sand fraction $(2-0.05 \mathrm{~mm})$ was found as well as the silt fraction $(0.05-0.002 \mathrm{~mm})$. An interesting element of the analysis was the lack of the smallest particles $(<0.002 \mathrm{~mm})$ forming the clay fraction. The addition of bentonite with the grain-size composition of silt loam resulted in the creation of a material with a high capacity to form macrostructures as a result of the sticking of individual grains to one another. As a result, nearly half of the agglomerates with a replacement diameter of more than $2 \mathrm{~mm}$ were present in the mass. The sieve fraction of the material prepared from bottom ash and bentonite had the grain size of clay (Table 3).

Table 3. Grain-size composition of ash, bentonite and the granulate produced from them.

\begin{tabular}{|c|c|c|c|c|c|c|}
\hline \multirow{2}{*}{ Material Analysed } & \multicolumn{2}{|c|}{ Sieve Analysis (\%) } & \multicolumn{3}{|c|}{ Hydrometric Analysis (\%) } & \multirow{2}{*}{ Material } \\
\hline & $<2 \mathrm{~mm}$ & $>2 \mathrm{~mm}$ & $2-0.05 \mathrm{~mm}$ & $0.05-0.002 \mathrm{~mm}$ & $<0.002 \mathrm{~mm}$ & \\
\hline Ash & 82.8 & 17.2 & 85 & 15 & 0 & Sand (S) \\
\hline Bentonite & 100.0 & 0.0 & 23 & 52 & 25 & Silt loam (SiL) \\
\hline Ash + bentonite & 51.3 & 48.7 & 73 & 22 & 5 & Loamy sand (LS) \\
\hline
\end{tabular}

The grain-size composition is the most important property of mineral materials. It represents the percentage of individual fractions, i.e., particles with a specific diameter in the material. Differences in the share of individual soil fractions directly affect the diversity of physical and chemical properties of materials, especially in terms of water and ion sorption and the ability to form macrostructures. In soil science, the diameter of $2 \mathrm{~mm}$ is the division line between particles belonging to the soil skeleton and granular parts. The analysis showed that the ash produced was skeletal and very sandy, which means that it might not be very useful as a fertilizer or soil improver. In the ash analysed in this study, there is a shift towards coarser fractions in comparison to the data found in the literature $[14,19,20]$. However, it should be noted that the size of ash particles depends on the type of fuel and fuel combustion technique, including the combustion temperature $[14,20]$.

The analysis of the ash from biomass pellets showed that the material had not burnt completely. The total carbon content was $14-21 \%$, with the dominance of TOC. The content of TOC in the fraction above $2 \mathrm{~mm}$ was higher by $36 \%$ than in the fine fraction below $2 \mathrm{~mm}$. Since bentonite is a mineral material, it had a low content of total carbon (2.99\%). The calorific value of the ash was $5.32-11.12 \mathrm{MJ} \cdot \mathrm{kg}^{-1}$. The ash had a strong alkaline reaction, whereas the bentonite was alkaline. After the addition of the bentonite to the ash, the $\mathrm{pH}$ value decreased as expected to an intermediate value between the mixed components. All of the materials were characterized by high specific conductivity, which reflected the content of salts dissolved in the water. The bentonite had a higher content of carbonates than the ash, which resulted in an increase of their content in the mixture produced (Table 4).

Table 4. Basic physical and chemical properties of the ashes, the bentonite and the granulate produced from them.

\begin{tabular}{|c|c|c|c|c|c|c|}
\hline \multirow{2}{*}{ Material Analysed } & \multicolumn{3}{|c|}{ Carbon Content (\%) } & \multirow{2}{*}{$\mathrm{pH}-\mathrm{H}_{2} \mathrm{O}$} & \multirow{2}{*}{$\begin{array}{c}\mathrm{EC} \\
\mathrm{mS} \cdot \mathrm{cm}^{-1}\end{array}$} & \multirow{2}{*}{$\frac{\mathrm{CaCO}_{3}}{\%}$} \\
\hline & TOC & IC & TC & & & \\
\hline Ash; fraction $<2 \mathrm{~mm}$ & 13.55 & 0.45 & 14.00 & 10.3 & 8.13 & 4.54 \\
\hline Ash; fraction $>2 \mathrm{~mm}$ & 21.19 & 0.11 & 21.30 & 10.2 & 8.13 & 4.54 \\
\hline Bentonite & 2.29 & 0.70 & 2.99 & 8.9 & 10.00 & 7.95 \\
\hline Ash (fraction $<2 \mathrm{~mm}$ ) + bentonite & 11.30 & 0.50 & 11.80 & 9.1 & 9.70 & 6.81 \\
\hline
\end{tabular}

According to Reference [1], the results described in Table 4 were relative high. But in several descriptions the similar ones or even higher TC content can be found [6,17]. Lanzerstorfer [14] showed that there was a relationship between the content of TC in ash and the fraction of this material. He noted 
that the content of TC was higher in the smallest fractions than in the thicker ones. These data were not confirmed in this study. The results showed that the content of TC was $7.3 \%$ higher in the fraction $>2 \mathrm{~mm}$ than in the material with a diameter $<2 \mathrm{~mm}$. The results obtained in this study suggest that it might be a good idea to treat the coarse and the fine ash fractions separately after their initial separation by sieving. This concept was presented by James et al. [6] also.

The $\mathrm{pH}$ values of ash were high, as was expected. Although it is mentioned in some publications that the reaction of ash from the combustion of clean straw can be lower ( $\mathrm{pH} 5-9)[23,24]$. On the other hand, some researchers [16] reported similar ( $\mathrm{pH} 10-11)$ or even higher ( $\mathrm{pH}$ above 12) [25] values for the ash from biomass. The unusually high $\mathrm{pH}$ of bentonite- $\mathrm{pH}-\mathrm{H}_{2} \mathrm{O}$ 8.8-8.9 (the expected value for clay material based on montmorillonite group minerals was below 5.0) suggests that the crystalline structure of clay minerals was partially substituted with sodium and calcium. This method of bentonite preparation, e.g., by the addition of ammonia soda, is a procedure used by many manufacturers.

In the ash analysed in this study, which was obtained from the combustion of plant biomass, the content of carbonates was relatively low in comparison to the data found in the literature, e.g., about $12 \% \mathrm{CaCO}_{3}$ according to Lima et al. [24].

While analysing the ash used in this study the subtotal content of components important in terms of fertilizing properties, it is necessary to note the content of $7.2 \% \mathrm{~K}, 12.9 \% \mathrm{Ca}, 0.79 \% \mathrm{Fe}, 1.75 \% \mathrm{Mg}$. It is noteworthy that in the bentonite there was a high content of $\mathrm{Na}$ (nearly $0.5 \%), \mathrm{Ca}(\sim 0.8 \%), \mathrm{K}(\sim 1.6 \%)$, $\mathrm{Mg}(1.5 \%)$ and $\mathrm{Cu}\left(\sim 52 \mathrm{mg} \cdot \mathrm{kg}^{-1}\right)$.

The analysis of the chemical composition of ash from biomass showed a high content of $\mathrm{Si}, \mathrm{Ca}, \mathrm{K}$, $\mathrm{Mg}$, $\mathrm{Al}$ and $\mathrm{Fe}$. It is also noteworthy that there was a relatively high content of $\mathrm{Mn}-3840 \mathrm{mg} \cdot \mathrm{kg}^{-1}$, $\mathrm{Zn}-236 \mathrm{mg} \cdot \mathrm{kg}^{-1}, \mathrm{Cr}-230 \mathrm{mg} \cdot \mathrm{kg}^{-1}$ and $\mathrm{Cu}-66.4 \mathrm{mg} \cdot \mathrm{kg}^{-1}$ (Table 5).

Table 5. Chemical composition of ash obtained from biomass pellets.

\begin{tabular}{|c|c|c|c|c|c|c|c|}
\hline \multicolumn{8}{|c|}{ (\% d.m.) } \\
\hline $\mathrm{P}$ & $\mathrm{K}$ & $\mathrm{Ca}$ & $\mathrm{Mg}$ & $\mathrm{Na}$ & $\mathrm{Si}$ & $\mathrm{Al}$ & $\mathrm{Fe}$ \\
\hline 0.16 & 7.19 & 12.90 & 1.75 & 0.45 & 26.51 & 0.64 & 0.79 \\
\hline \multicolumn{8}{|c|}{ (mg.kg ${ }^{-1}$ d.m.) } \\
\hline $\mathrm{Cl}$ & $\mathrm{Cd}$ & $\mathrm{Cr}$ & $\mathrm{Cu}$ & $\mathrm{Mn}$ & $\mathrm{Ni}$ & $\mathrm{Pb}$ & $\mathrm{Zn}$ \\
\hline$<100$ & 2.17 & 230 & 66.4 & 3840 & 81.4 & 0.77 & 236 \\
\hline
\end{tabular}

The content of Ca in the ash was high compared to the findings of References [16,23,24]; it oscillates around the highest value of the content found by Ribbing [43] and is well below the value reported by other authors $[2,6,17,25,26]$. In general, the content of $\mathrm{Ca}$ in ash biomass varies greatly depending on its origin, ranging from 3.6 to $35.3 \%$ [12]. The content of $\mathrm{K}$ was medium in the ash analysed. In the literature, the content of $\mathrm{K}$ in ash from wood biomass is given as $1.9-29 \%[1,2,16-18]$. The content of $\mathrm{P}$ was almost 2 times lower than reported by Cuellar and Herzog [2] and Saletnik et al. [16], and many times lower than the data reported by Zajac et al.-0.3-3.3\%. The content of $\mathrm{Cl}$ in this study it was very low-lower by at least one order of magnitude than indicated in the literature $[1,2,18]$. The content of Fe should be regarded as relatively low when compared to the results in references $[2,17,43]$ but it is high in the context of the other data $[12,23,25,26]$. A medium content of $\mathrm{Mg}$ was found when compared to the results in references $[2,16,17,43]$ but it was high in the context of the other data $[23,25,26]$.

Taking into account the need to protect the environment, especially when using waste material as fertilizer, the content of selected metals was analysed. The high content of aluminium-more than seven times higher than recorded by Hansen et al. [23] is not very worrying. However, in other studies [2] a similar content was found to the content recorded in this study. The content of manganese should be assessed in the same way, although in this case the level of $0.3 \%$ was low when compared to the data provided by Cuellar and Herzog [2], average when compared to the studies by Ribbing [43] and Zajac et al. [12], and high when compared to the studies by Bakisgana et al. [26] and Saletnik et al. [16]. A different approach should be taken in the case of the group of so-called heavy metals that 
have a long-term impact on the environment because they can be accumulated. The ash analysed was characterized by a content of As and Se below the limit of detection and a low content of $\mathrm{Cd}$ and $\mathrm{Pb}$. These values were expected and described in the literature [12,14,18-20]. The very high content of $\mathrm{Cr}$ is noteworthy. It is by one to two orders of magnitude higher than reported by Hansen et al. [23], Bakisgana et al. [26], Lima et al. [24], Gibczyńska et al. [20] and Cuellar and Herzog [2], two orders of magnitude higher than reported by Stankowski et al. [25] for straw, seven times higher than reported by Antonkiewicz and Pełka [19] and Stankowski et al. [25] for wood, 5.5 times higher than reported by Nurmesniemi et al. [18], four times higher than reported by Smirit et al. [44], 2.5 times higher than reported by Zajac et al. [12], but within the lower limits of the range reported by Ribbing [43] and comparable with the data reported by Saletnik et al. [16]. The Cu content of $66.4 \mathrm{mg} \mathrm{Cu} \cdot \mathrm{kg}^{-1}$ was medium in comparison to References [12,16,19] and Stankowski et al. [25] for straw, or two times lower $[25,44]$ for wood. The content of Ni was moderately low or medium according to most authors, excluding the level reported by Smirit et al. [44], Antonkiewicz and Pełka [19], Gibczyńska et al. [20] and Hansen et al. [23], who respectively indicated a 2 times, 2.5 times, 4 times and 15 times lower content in the biomass ash analysed by them. Stankowski et al. [25] found that the content of Ni was 2.5 times lower in wood ash and 27 times lower in straw ash. The content of $\mathrm{Zn}$ was distinct, slightly higher than found by Saletnik et al. [16] but 2.5 times higher than reported by Gibczyńska et al. [20] and three times higher than in the data provided by Antonkiewicz and Pełka [19]. The values obtained by Zajac et al. [12] were similar to the ones recorded in this study, and the values obtained by Cuellar and Herzog [2] and Stankowski et al. [25] were much higher. The content of $\mathrm{Zn}$ found in this study shows that this element is not a problem as far as the natural use of this ash is concerned.

Bentonite should be regarded as an ecologically pure material, although the composition of the bentonite used in this study indicates that it was prepared by saturating the sorption complex with alkaline cations. However, this does not pose any risk in terms of its use as a binder for granules made from ash.

An important aim of this study was to determine the potential mobility of the components present in the ash used. It was also noted that the addition of bentonite, used as a granule-binding component, played a very important role in the phenomenon under analysis. In this way, one of the predefined tasks for this material was achieved-stabilisation of the behaviour of ash components. The use of bentonite as a clay material based on montmorillonite (2:1 type clay mineral), possible because of its extensive sorption properties, is well known in the literature $[27,28,45]$. It is particularly noteworthy that the potential mobility of $\mathrm{Cr}$ present in the ash in a large amount was low- $4.5 \%$, which was further reduced to $2.7 \%$ by the addition of bentonite. This index was also low for $\mathrm{Ni}-6.6 \%$, reduced to $4.0 \%$ by the addition of bentonite. However, a large potential availability of other components was noted: $\mathrm{Cd}(93.5 \%), \mathrm{Pb}(89.6 \%), \mathrm{Na}(77.7 \%), \mathrm{Al}(56 \%)$ and $\mathrm{K}(45.9 \%)$. By the addition of bentonite these indices decreased to: $\mathrm{Cd}(48.4 \%), \mathrm{Pb}(46.8 \%), \mathrm{Na}(54.6 \%), \mathrm{Al}(35.7 \%)$ and $\mathrm{K}(32.1 \%)$ (Figure 3$)$. In the literature, it is possible to find much information on the low solubility of a number of components in water, mainly from the group of heavy metals $(\mathrm{Cd}, \mathrm{Cu}, \mathrm{Ni}, \mathrm{Zn})$, due to the alkalinity of bottom ash [46].

\subsection{Analysis of the Chemical Composition of the Substrates}

As a result of admixing ash granulate to the greenhouse substrate with a neutral $\mathrm{pH}$, the content of $\mathrm{Ca}, \mathrm{K}, \mathrm{Cd}, \mathrm{Cr}, \mathrm{Ni}$ and $\mathrm{Zn}$ increased, and the content of $\mathrm{Cu}$ was reduced. In the greenhouse substrate with an acidic $\mathrm{pH}$, after the addition of ash granulate, the content of $\mathrm{Ca}, \mathrm{K}, \mathrm{Mg}, \mathrm{Cd}, \mathrm{Cr}, \mathrm{Cu}$ and $\mathrm{Zn}$ increased, and the content of $\mathrm{Ni}$ decreased with low doses, but it increased when the highest dose was added. The substrates for field cultivation were prepared from mineral material obtained from the soil of arable land where experimental plants were cultivated. As a result of admixing ash granulate to the soil of the field crops, the content of $\mathrm{Ca}, \mathrm{K}, \mathrm{Mg}, \mathrm{Cd}, \mathrm{Cr}, \mathrm{Ni}$ and $\mathrm{Zn}$ increased, and the content of $\mathrm{Cu}$ decreased. The distribution of the content of $\mathrm{Pb}$ in the experimental combinations was uneven (Figures 4 and 5). 


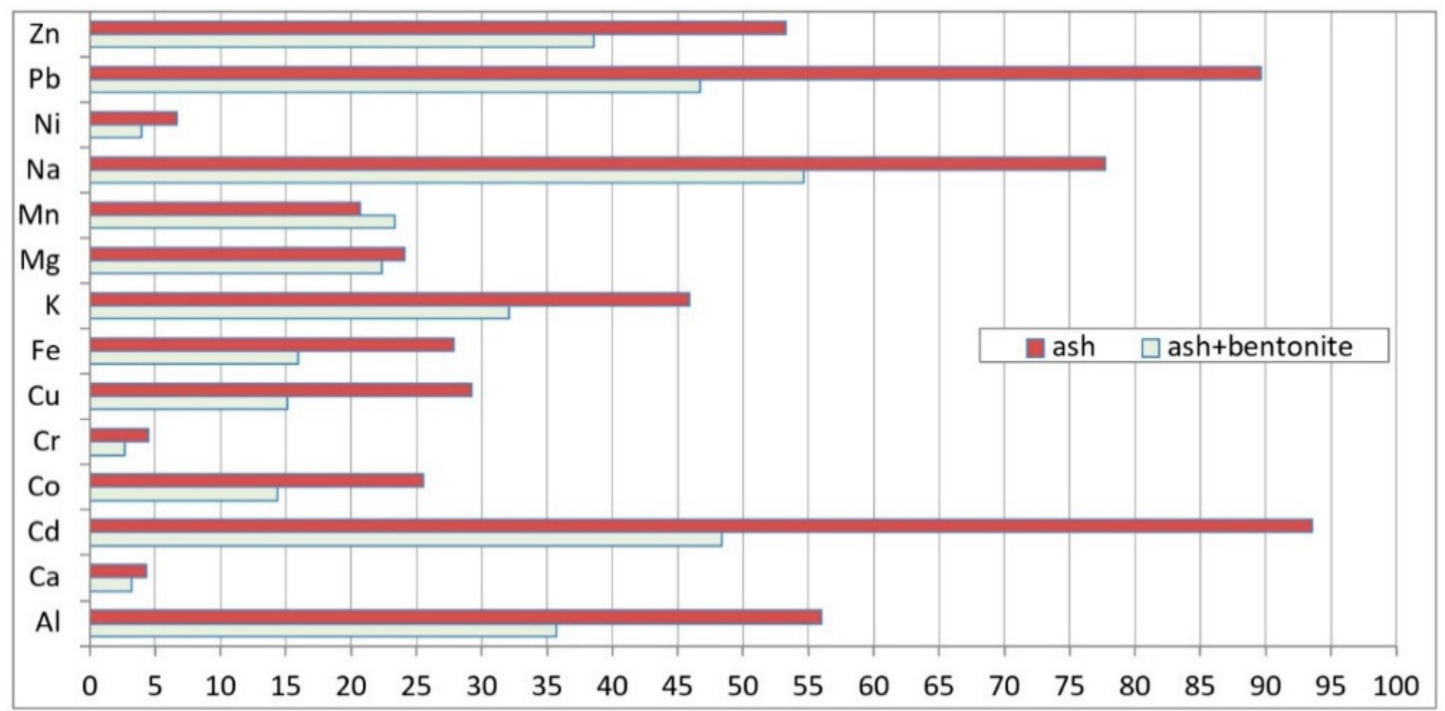

Figure 3. Percentage share of the form potentially available to plants in the ash (dissolved in $0.1 \mathrm{M}$ $\mathrm{HCl})$ in a subtotal content of selected components.

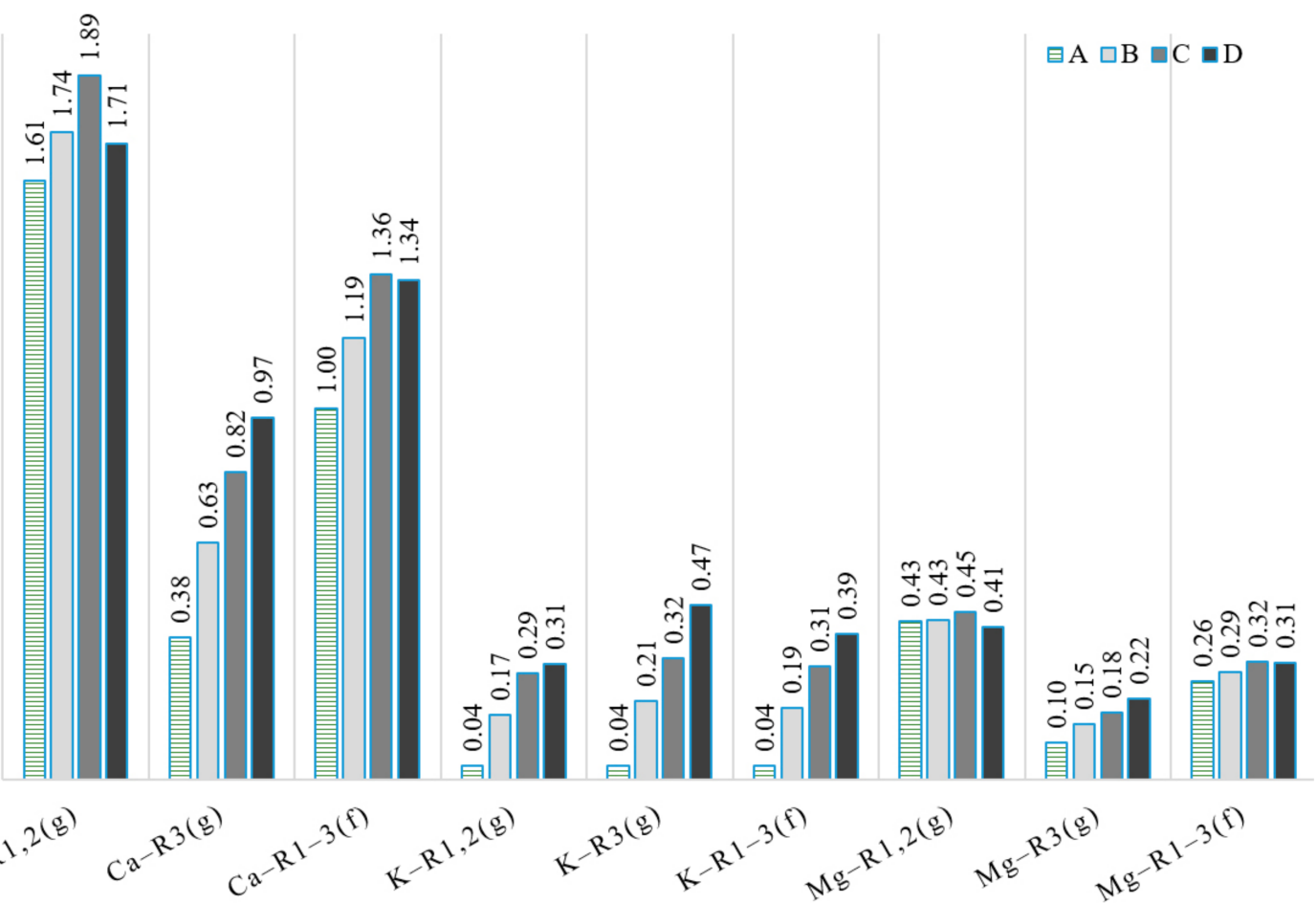

Figure 4. Subtotal content of selected macrocomponents in the substrates and in the soil (in \% of dry matter, d.m.); g-greenhouse, f-field.

An increase in the content of $\mathrm{Ca}$ and $\mathrm{K}$ in the substrates and the soil was expected and is described in the literature as a reaction to fertilization with ash from biomass [16,25]. However, these authors did not report a significant increase in the content of metallic elements in soil, which is contradictory to the increase in the content of $\mathrm{Cd}, \mathrm{Cr}, \mathrm{Cu}, \mathrm{Mg}$ and $\mathrm{Zn}$ observed in this study. Gibczyńska et al. [20] reported an increase in the content of $\mathrm{K}$ and $\mathrm{Mg}$ forms available for plants in soil after fertilization with a dose of $1.5 \mathrm{t} \cdot \mathrm{ha}^{-1}$ biomass ash by $10 \%$ and $21 \%$ respectively. They did not report a statistically significant increase in the content of $\mathrm{Cd}, \mathrm{Cu}, \mathrm{Mn}, \mathrm{Zn}$ and $\mathrm{Pb}$, whereas the content of $\mathrm{Ni}$ in soil increased significantly—by $36 \%$. Antonkiewicz and Pełka [19] observed a decrease in the content of $\mathrm{Cr}, \mathrm{Zn}, \mathrm{Pb}$, 
$\mathrm{Cd}$ and $\mathrm{Ni}$ as a result of fertilizing soil with a mixture of peat and ash, due to the low content of these elements in these components.

\subsection{Analysis of the Chamical Composition of the Plants}

The content of the components analysed in the plants grown on control substrates (combination A) was within a range that is considered to be standard for the chemical composition of plants [47,48]. In the literature, there are similar results for begonias [6,49] as the ones obtained in this study (Figures 6 and 7). Grigatri et al. [50] noted that in the above-ground parts of begonias the content of $\mathrm{As}, \mathrm{Ca}, \mathrm{Cu}, \mathrm{K}, \mathrm{Mg}$ and $\mathrm{Na}$ could be even higher than recorded in this study. Conifers growing in acidic conditions also had chemical properties similar to the ones found in a number of publications [51,52].

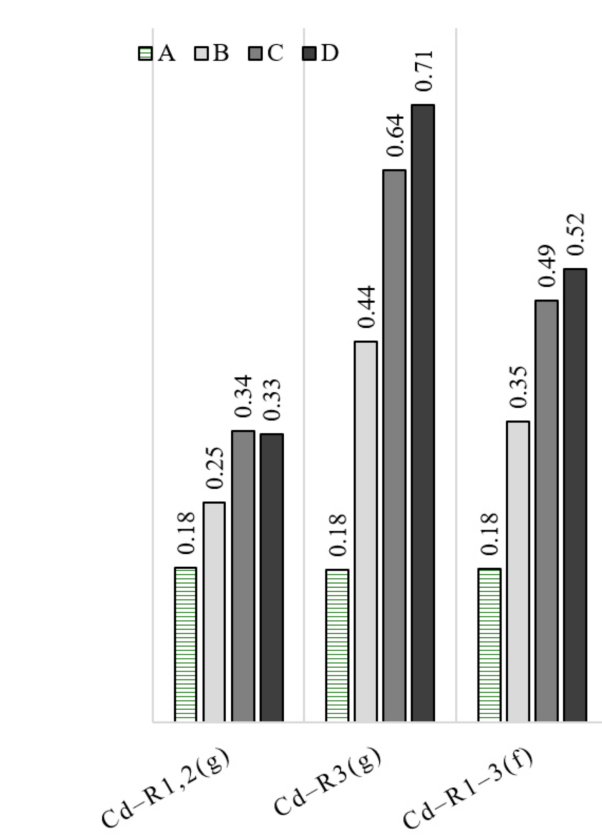

(a)

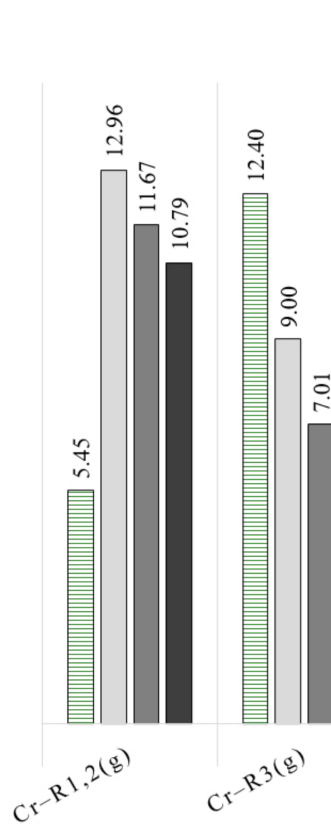

$\stackrel{\circ}{\ddagger}$

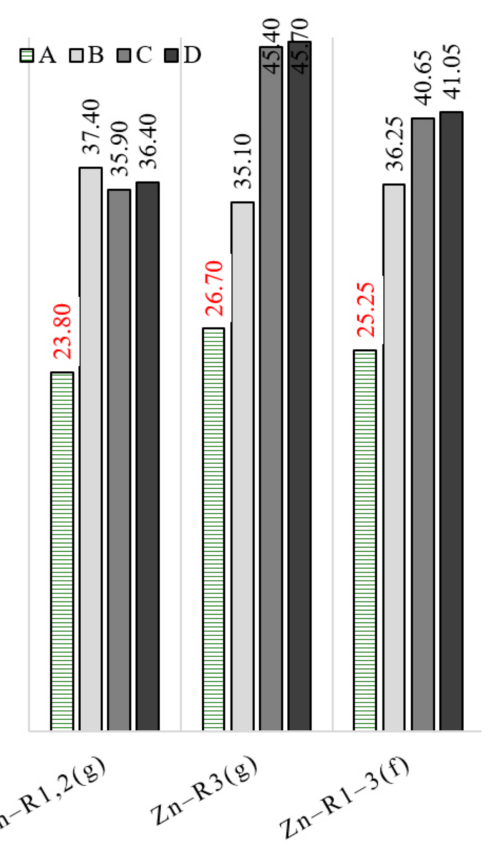

(b)

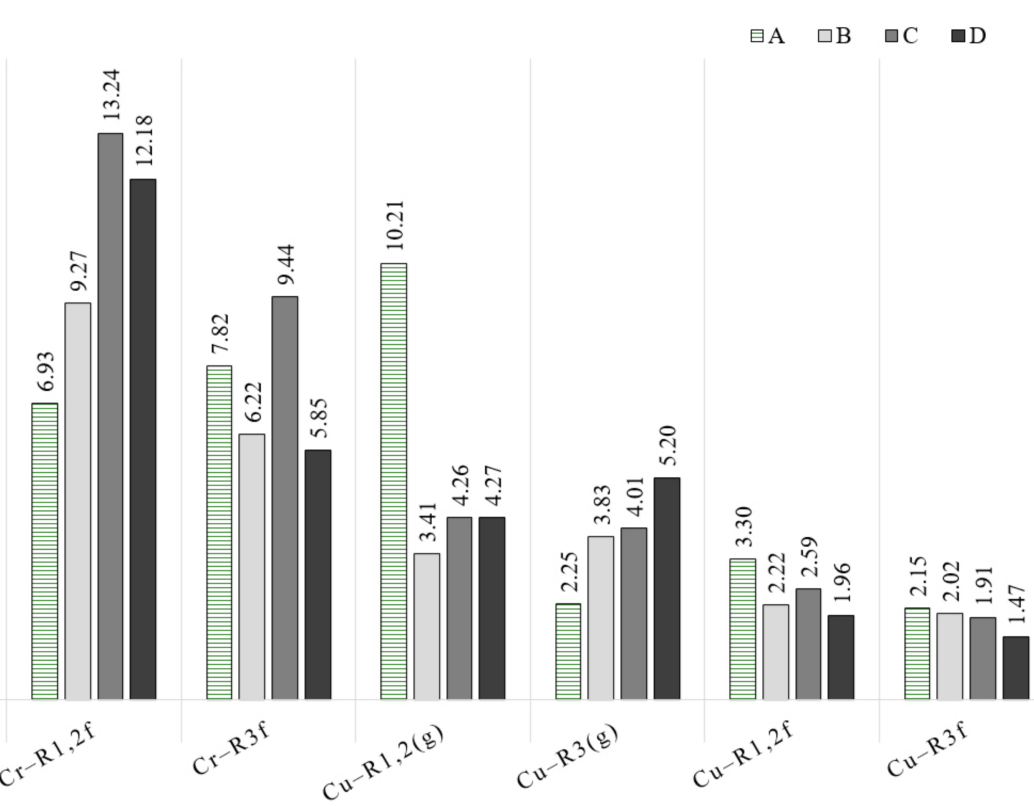

(c)

Figure 5. Cont. 


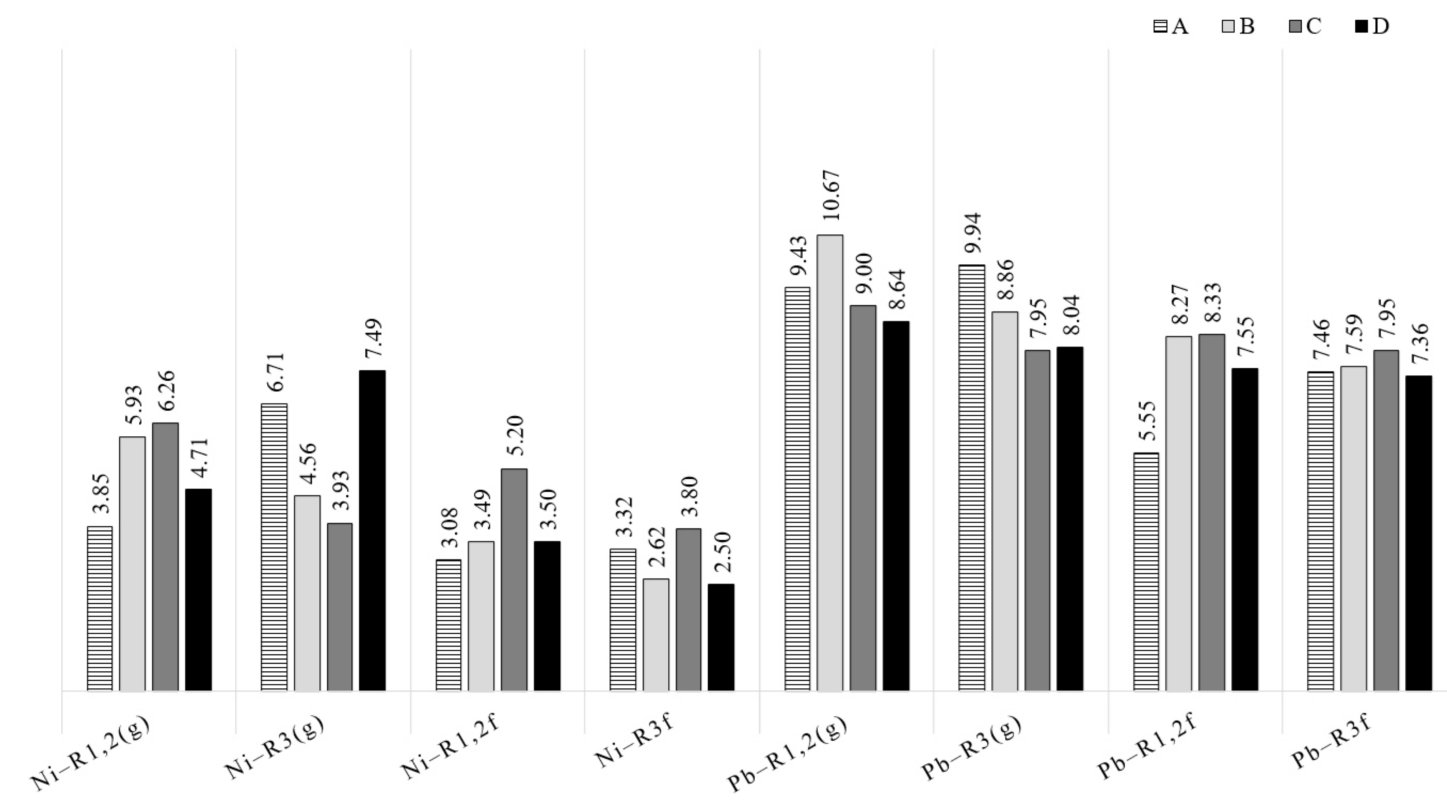

(d)

Figure 5. Subtotal content of selected heavy metals in the substrates and in the soil (in $\mathrm{mg} \cdot \mathrm{kg}^{-1} \mathrm{~d} . \mathrm{m}$.); g-greenhouse, f-field; (a) Cd content (b) Zn content (c) Cr and Cu content (d) Ni and Pb content.

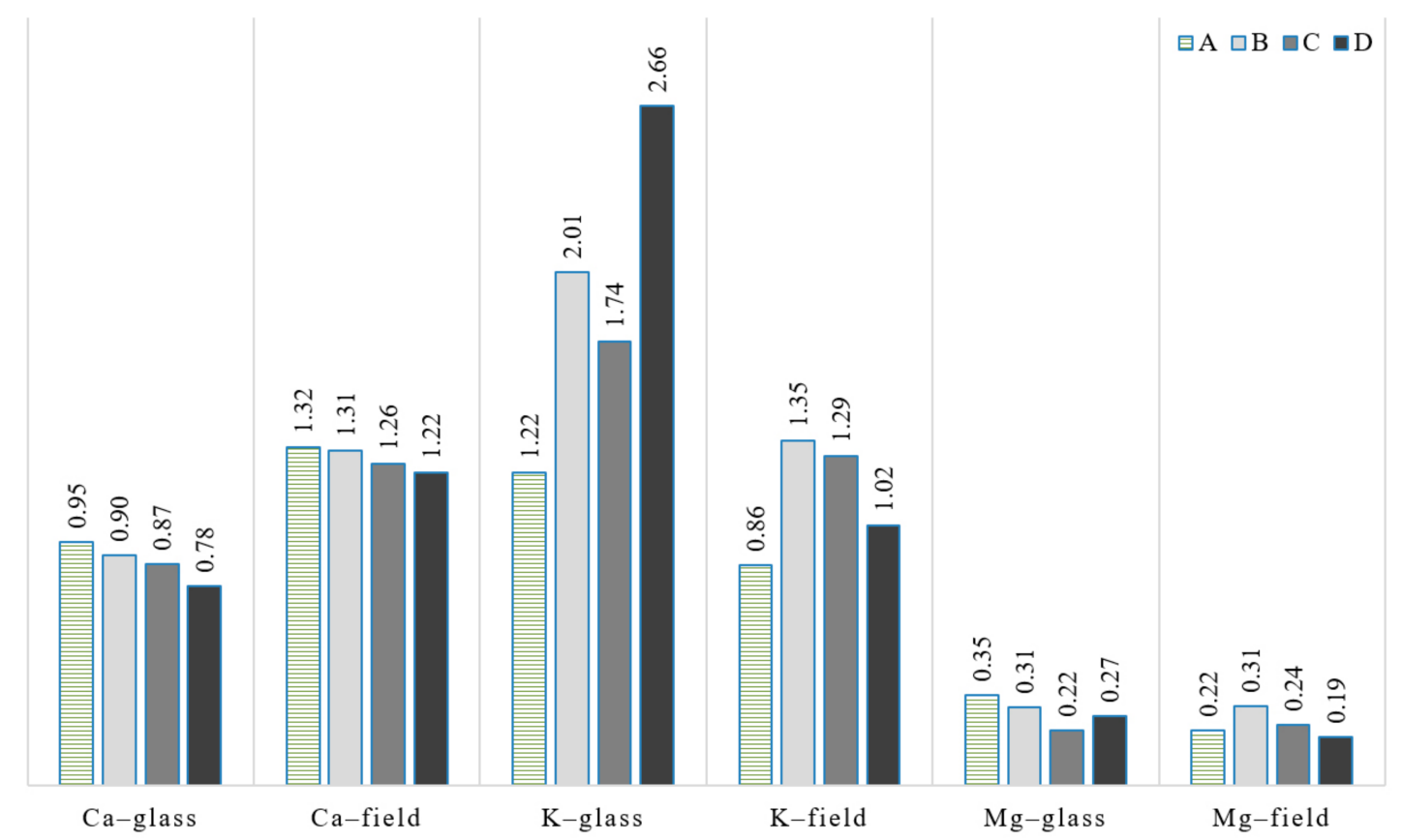

Figure 6. Average content of $\mathrm{Ca}, \mathrm{K}$ and $\mathrm{Mg}$ in the test plants cultivated in the greenhouse and in the field (in \% d.m.).

The addition of ash to the substrates changed the relationship between the soil and the plants. The plants collected $\mathrm{Ca}$ in a smaller amount as the doses of ash granulate increased. As far as $\mathrm{K}$ and $\mathrm{Mg}$ were concerned, no clear correlation was found in the case of the greenhouse plants. In the case of the field plants, there was a significant increase in the uptake of $\mathrm{K}$ and $\mathrm{Mg}$ when the lowest dose was used. Later, lower values were observed in succession, although the content of $\mathrm{K}$ was always higher than in the control combination. The content of $\mathrm{Mg}$ was lower than in the control combination only when the highest dose of ash granulate was used (Figure 6). Saletnik et al. [16] presented similar 
relations in their studies, indicating an increase in the uptake of $\mathrm{Ca}, \mathrm{Mg}$ and $\mathrm{K}$ by plants fertilized with ash. However, they noted significant differences in the collection of these elements in subsequent years of their experiments, as well as in the case of different ash variants.

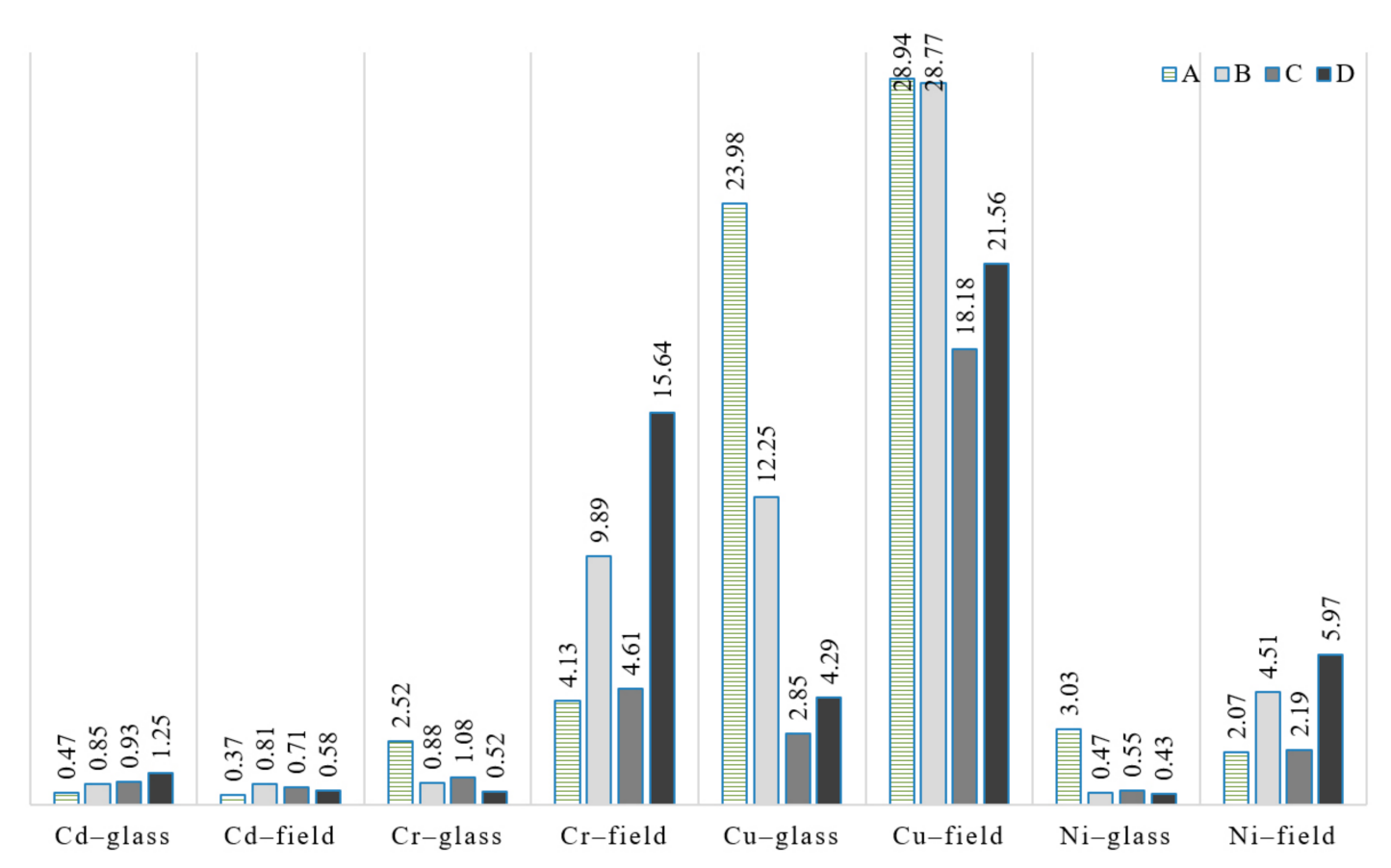

Figure 7. Average content of $\mathrm{Cd}, \mathrm{Cr}, \mathrm{Cu}$ and $\mathrm{Ni}$ in the test plants cultivated in the greenhouse and in the field (in $\mathrm{mg} \cdot \mathrm{kg}^{-1} \mathrm{~d} . \mathrm{m}$.).

Because of the nature of the test plants (ornamental plants), an important point to consider is the overall content of heavy metals in their biomass since it affects their possible use after removal from green areas. There was a problem with an increased uptake of $\mathrm{Cd}$ from the greenhouse substrates. This problem was slightly smaller in the case of the plants grown in the field. There was also a large uptake of $\mathrm{Cr}$ and $\mathrm{Ni}$ by the field plants when the highest dose of ash was used (Figure 7).

Saletnik et al. [16] did not observe such reactions of plants to increasing doses of ash from biomass used for soil fertilization. Stankowski et al. [25] noted a similar lack of a statistically significant reaction after the addition of ash from wood and straw biomass to the soil. In order to provide full information on the uptake of heavy metals by plants, it is necessary to note the differences between the species and parts of the plants analysed.

Even the smallest dose of ash added to the substrates (combination B) resulted in an increase in the accumulation of heavy metals in the test plants in comparison to the data [6,47-52], in some cases the toxicity threshold (signed as a underlined numbers) was exceeded - Table $6[47,48,50,51]$ :

- $\quad$ in the greenhouse:

- increased uptake of $\mathrm{Cd}$ and $\mathrm{Cr}$ by the begonias and the thujas and $\mathrm{Cu}$ by the begonias in comparison to the standard content of these elements in plants;

- Cd content tolerable in agronomic crops exceeded six times in the roots of the thujas $\left(3.18 \mathrm{mg} \cdot \mathrm{kg}^{-1}\right)$;

- in the field:

- increased uptake of $\mathrm{Cd}$ and $\mathrm{Cu}$ by the roots and $\mathrm{Ni}$ by the aboveground parts of the begonias in comparison to the standard content of these elements in plants; 
- Cr content tolerable in agronomic crops exceeded 20 times in the aboveground parts of the

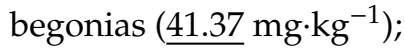

- increased uptake of $\mathrm{Ni}$ by the thujas (in the roots) and $\mathrm{Cu}$ (in the aboveground parts) and $\mathrm{Cd}$ and $\mathrm{Cr}$ in all parts of the plants in comparison to the standard content of these elements in plants;

- Cr content tolerable in agronomic crops exceeded in all parts of the pelargoniums (3-9.11 $\left.\mathrm{mg} \cdot \mathrm{kg}^{-1}\right)$;

- $\mathrm{Cu}$ content tolerable in agronomic crops exceeded in the aboveground parts of the thujas $\left(\underline{68.3} \mathrm{mg} \cdot \mathrm{kg}^{-1}\right)$, and the $\mathrm{Cd}$ and $\mathrm{Cr}$ threshold exceeded in the roots (respectively $3.52 \mathrm{mg} \cdot \mathrm{kg}^{-1}$ and $4.49 \mathrm{mg} \cdot \mathrm{kg}^{-1}$ ).

Table 6. The normal content and toxicity threshold values of the chosen elements in plants, in $\mathrm{mg} \cdot \mathrm{kg}^{-1}[47,48]$.

\begin{tabular}{ccccccc}
\hline Element & $\mathbf{C d}$ & $\mathbf{C r}$ & $\mathbf{C u}$ & $\mathbf{N i}$ & $\mathbf{P b}$ & $\mathbf{Z n}$ \\
\hline Normal content & $0.05-0.2$ & $0.1-0.5$ & $5-30$ & $0.1-5$ & $5-10$ & $27-150$ \\
Toxicity threshold & $5-30$ & $5-30$ & $20-100$ & $10-100$ & $30-300$ & $100-400$ \\
Tolerable in agronomic crops & $0.05-0.5$ & 2 & $5-20$ & $1-10$ & $0.5-10$ & $50-100$ \\
\hline
\end{tabular}

Higher doses of ash granulate (combination C) resulted in:

- in the greenhouse:

- increased uptake of $\mathrm{Cd}$ by the roots and $\mathrm{Cr}$ by all parts of the begonias, and $\mathrm{Cr}$ by the aboveground parts of the thujas in comparison to the standard content of these elements in plants;

- Cd content tolerable in agronomic crops exceeded over seven times in aboveground parts of the thujas $\left(3.79 \mathrm{mg} \cdot \mathrm{kg}^{-1}\right)$;

- in the field:

- increased uptake of $\mathrm{Cd}$ and $\mathrm{Cu}$ by the roots of the begonias in comparison to the standard content of these elements in plants;

- increased uptake of $\mathrm{Cd}$ and $\mathrm{Cr}$ by the thujas in all parts of the plants in comparison to the standard content of these elements in plants;

- $\mathrm{Cr}$ content tolerable in agronomic crops exceeded in all parts of the pelargoniums $\left(2.85-10 \mathrm{mg} \cdot \mathrm{kg}^{-1}\right)$;

- Cr content tolerable in agronomic crops exceeded seven times in the roots of the begonias

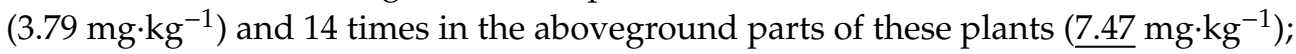

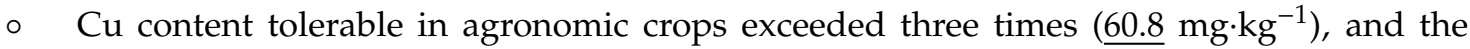
$\mathrm{Cd}$ content tolerable in agronomic crops exceeded two times in the roots of the begonias $\left(0.98 \mathrm{mg} \cdot \mathrm{kg}^{-1}\right)$;

- $\mathrm{Cd}$ and $\mathrm{Cr}$ content tolerable in agronomic crops exceeded in the roots of the thujas (respectively $3.35 \mathrm{mg} \cdot \mathrm{kg}^{-1}$ and $2.5 \mathrm{mg} \cdot \mathrm{kg}^{-1}$ ).

The largest dose of ash granulate (combination D) resulted in:

- in the greenhouse:

- increased uptake of $\mathrm{Cr}$ by the shoots and leaves of the geraniums, the roots of the begonias and the roots of the thujas in comparison to the standard content of these elements in plants; 
- increased uptake of Cd by all parts of the plant;

- $\mathrm{Cd}$ content tolerable in agronomic crops exceeded in all parts of the begonias $\left(0.7-0.98 \mathrm{mg} \cdot \mathrm{kg}^{-1}\right)$;

- Cd content tolerable in agronomic crops exceeded 11 times in the roots of the thujas $\left(5.51 \mathrm{mg} \cdot \mathrm{kg}^{-1}\right)$;

- in the field:

- increased uptake of $\mathrm{Cd}$ and $\mathrm{Cu}$ by the roots, $\mathrm{Cr}$ by all parts and $\mathrm{Ni}$ in the aboveground parts of the begonias in comparison to the standard content of these elements in plants;

- increased uptake of $\mathrm{Cr}$ by the thujas in all parts and $\mathrm{Cd}$ in the roots in comparison to the standard content of these elements in plants;

- Cr content tolerable in agronomic crops exceeded in all parts of the pelargoniums (5.97-20.6 $\left.\mathrm{mg} \cdot \mathrm{kg}^{-1}\right)$;

- Cr content tolerable in agronomic crops exceeded in all parts of the begonias, including 11 times in the aboveground parts $\left(55.27 \mathrm{mg} \cdot \mathrm{kg}^{-1}\right)$, the $\mathrm{Cd}$ content tolerable in agronomic crops slightly exceeded in the roots $\left(0.56 \mathrm{mg} \cdot \mathrm{kg}^{-1}\right)$, the $\mathrm{Cu}$ content tolerable in agronomic crops exceeded almost four times in the roots $\left(\underline{77.4} \mathrm{mg} \cdot \mathrm{kg}^{-1}\right)$, and the Ni content tolerable in agronomic crops exceeded 2.5 times in the aboveground parts $\left(\underline{24.9} \mathrm{mg} \cdot \mathrm{kg}^{-1}\right)$;

- Cd content tolerable in agronomic crops exceeded and the $\mathrm{Cr}$ content tolerable in agronomic crops exceeded six times in the roots of the thujas $\left(2.99 \mathrm{mg} \cdot \mathrm{kg}^{-1}\right)$.

The analysis of the morphology of the test plants shows that only the largest dose resulted in very clear symptoms such as slow growth, chlorosis and necrosis on the leaves of all of the plants, and these symptoms were much stronger in the pelargoniums and begonias than in the thujas. Investigations of Saletnik et al. confirm that the yield of crops decreases when biomass ash is used as fertilizer [16]. Although, they noted a slight increase in the yield of Miscanthus biomass with a dose of $1.5 \mathrm{t} \cdot \mathrm{ha}^{-1}$, subsequent doses of $3 \mathrm{t} \cdot \mathrm{ha}^{-1}$ and $4.5 \mathrm{t} \cdot \mathrm{ha}^{-1}$ resulted in a noticeable decrease in the yield [16].

A multiple regression analysis was performed in order to present the relationship between the content of the components in the base substrate and their content in the plant biomass. In the case of the greenhouse plants, with the assumed significance level of $a=0.05$, only the relation between the content of $\mathrm{K}$ in the base substrate and its content in the roots of the thujas (correlation coefficient $r=0.99$ ) was considered to be statistically significant. In the case of the field plants, the following relations were considered to be statistically significant:

- relation between Ca in the substrate and in the biomass of the bedding pelargoniums (correlation coefficient $r=-0.97$ ) and the begonias (correlation coefficient $r=0.97$ ),

- relation between $\mathrm{Mg}$ in the substrate and in the biomass of the begonias (correlation coefficient $\mathrm{r}=0.95)$,

- relation between $\mathrm{Ni}$ in the substrate and in the biomass of the bedding pelargoniums (correlation coefficient $r=0.99$ ).

\section{Conclusions and Perspectives for Further Research}

- A significant content of total carbon in the ash was noted, especially in its course fraction. For this reason, fertilization with ash may increase the carbon stock in soils and affect the soil sorption of elements.

- Ash from biomass combustion is a good neutralizer of soil and horticultural substrate. It is also a material rich in $\mathrm{Ca}, \mathrm{K}$ and $\mathrm{Mg}$.

- High bioavailability of $\mathrm{Pb}$ and $\mathrm{Cd}$ from ash as well as the relatively high availability of $\mathrm{Zn}$ are an environmental problem. The mobility of these heavy metals was significantly reduced by 
the admixture of bentonite during ash granulation. However, with high doses of ash pellets the uptake of $\mathrm{Cd}$ by the crop plants was high. We found it as a negative aspect, strongly affecting the possibility of the agricultural use of ash, counting the need to ensure ecological safety of such technology.

- During cultivation, $\mathrm{Cr}$ was activated, which results in the presence of high concentrations of this element in the plants cultivated on both the greenhouse substrates as well as on the soil in the field. We found it as another negative aspect, resulting from the use of ash as a fertilizer.

- Preparation of ash granulate with an admixture of bentonite in the proportion: $225 \mathrm{~g}$ bentonite and $775 \mathrm{~g}$ ash increased the sorption of components in this material and decreased their bioavailability but a significant release of heavy metals to the substrate was still noted. In the long run, this might be a significant problem if soil fertilized in this way is used for the cultivation of long-rotation plants.

Ash from solid fuels is used as a substitute for fertilizer lime. This problem has been relatively well researched, which is reflected by the large number of scientific publications on this subject. When we use ash in this way, we expect a fast effect that causes large changes in soils shortly after application and decreases with the passage of time. The granulation of ash before its application in soils makes it similar to long-acting fertilizers. Subsequent studies should deal with the durability of granulates prepared in different ways in soil, as well as the process of release of individual components from these granulates into soil. It would be advisable to show the differences between the application of ash and ash granulates within a few years after applying these two materials. It would also be advisable to make other granulates including organic matter and various clays, and to cover the granules with materials with adjustable permeability. This technique is used to prepare mineral fertilizers. It would be interesting to find out whether a similar technique could also be applied to ashes. Environmental problems connected with the presence of heavy metals in the ash were observed. Since heavy metals are characterized by relatively high bioavailability, in further research it would be necessary to determine their source and to analyse the release of these elements into the soil environment.

Author Contributions: A.G.-project scientific coordinator, indication of the idea of research, arrangement of the research work schedule, preparation of results, data analysis, paper preparation, correspondence author; M.M.-preparation of results, data analysis, paper preparation; W.S.- project leader, arrangement of the research work schedule, sampling, preparation and conducting analyzes, collecting data, paper preparation.

Funding: This study was funded by the European Union as part of the project "Heat from Native Biomass", No. WTBR.02.03.00-54-005/09, the Cross-Border Cooperation Operational Programme Poland (the Lubusz Voivodship)-Brandenburg 2007-2013, within European Territorial Cooperation, Priority II. Supporting economic links and cooperation between science and economy, Activity 2.3. Supporting networks and cooperation in the field of R \& D".

Conflicts of Interest: The authors declare no conflict of interest.

\section{References}

1. Zheng, Y.; Jensen, P.A.; Jensen, A.D.; Sander, B.; Junker, H. Ash transformation during co-firing coal and straw. Fuel 2006, 86, 1008-1020. [CrossRef]

2. Cuellar, A.D.; Herzog, H. A Path Forward for Low Carbon Power from Biomass. Energies 2015, 8, 1701-1715. [CrossRef]

3. Łączak, A.; Bazan-Krzywoszańska, A.; Mrówczyńska, M.; Skiba, M. Renewable energy sources in the Lubusz Voivodship (Poland). The present conditions and perspectives for development. Civ. Environ. Eng. Rep. 2018, 28, 31-67. [CrossRef]

4. Rybak, A. Poland's Energy Mix and Energy Security of the Country. World Sci. News 2019, 128, 402-415.

5. Ahmaruzzaman, M. A review on the utilization of fly ash. Prog. Energy Combust. Sci. 2010, 36, $327-363$. [CrossRef]

6. James, A.K.; Thring, R.W.; Helle, S.; Ghuman, H.S. Ash Management Review-Applications of Biomass Bottom Ash. Energies 2012, 5, 3856-3873. [CrossRef] 
7. García-Maraver, A.; Popov, V.; Zamorano, M. A review of European standards for pellet quality. Renew. Energy 2011, 36, 3537-3540. [CrossRef]

8. Houshfar, E.; Løvås, T.; Skreiberg, Ø. Experimental Investigation on NOx Reduction by Primary Measures in Biomass Combustion: Straw, Peat, Sewage Sludge, Forest Residues and Wood Pellets. Energies 2012, 5, 270-290. [CrossRef]

9. Tchapda, A.H.; Pisupati, S.V. A Review of Thermal Co-Conversion of Coal and Biomass/Waste. Energies 2014, 7, 1098-1148. [CrossRef]

10. Shao, Y.; Wang, J.; Preto, F.; Zhu, J.; Xu, C. Ash Deposition in Biomass Combustion or Co-Firing for Power/Heat Generation. Energies 2012, 5, 5171-5189. [CrossRef]

11. European Union Institutions, Bodies, Offices and Agencies. EU 2018/C 124/01 Commission Notice on Technical Guidance on the Classification of Waste. Off. J. Eur. Union 2018. Available online: https: //eur-lex.europa.eu/legal-content/EN/TXT/PDF (accessed on 9 April 2018).

12. Zając, G.; Szyszlak-Bargłowicz, J.; Gołębiowski, W.; Szczepanik, M. Chemical Characteristics of Biomass Ashes. Energies 2018, 11, 2885. [CrossRef]

13. Falemara, B.C.; Joshua, V.I.; Aina, O.O.; Nuhu, R.D. Performance Evaluation of the Physical and Combustion Properties of Briquettes Produced from Agro-Wastes and Wood Residues. Recycling 2018, 3, 37. [CrossRef]

14. Lanzerstorfer, C. Combustion of Miscanthus: Composition of the Ash by Particle Size. Energies 2019, $12,178$. [CrossRef]

15. Huinink, J.T.M. Soil quality requirements for use in urban environments. Soil Tillage Res. 1998, 47, 157-162. [CrossRef]

16. Saletnik, B.; Zagula, G.; Bajcar, M.; Czernicka, M.; Puchalski, C. Biochar and Biomass Ash as a Soil Ameliorant: The Effect on Selected Soil Properties and Yield of Giant Miscanthus (Miscanthus x giganteus). Energies 2018, 11, 2535. [CrossRef]

17. Cabrera, M.; Galvin, A.P.; Agrela, F.; Beltrán, M.; Ayuso, J. Reduction of Leaching Impacts by Applying Biomass Bottom Ash and Recycled Mixed Aggregates in Structural Layers of Roads. Materials 2016, 9, 228. [CrossRef]

18. Nurmesniemi, H.; Manskinen, K.; Poykio, R.; Dahl, O. Forest fertilizer properties of the bottom ash and fly ash from a large-sized (115 MW) industrial power plant incinerating wood-based biomass residues. J. Univ. Chem. Technol. Metall. 2012, 47, 43-52.

19. Antonkiewicz, J.; Pełka, R. Fractions of heavy metals in soil after the application of municipal sewage sludge, peat, and furnace ash. Soil Sci. Ann. 2014, 65, 118-125. [CrossRef]

20. Gibczyńska, M.; Stankowski, S.; Hury, G.; Kuglarz, K. Effects of limestone, ash from biomass and compost use on chemical properties of soil. Soil Sci. Ann. 2014, 65, 59-64. [CrossRef]

21. Tejasvi, A.; Kumar, S. Impact of Fly Ash on Soil Properties. Natl. Acad. Sci. Lett. 2012, 35, 13-16. [CrossRef]

22. Ćwiąkała, M.; Greinert, A.; Kostecki, J.; Rafalski, L. The possibility to use modified flight ash as a neutralizer in the acid soils reclamation processes. Civ. Environ. Eng. Rep. 2018, 28, 88-104. [CrossRef]

23. Hansen, H.K.; Pedersen, A.J.; Ottosen, L.M.; Villumsen, A. Speciation and mobility of cadmium in straw and wood combustion fly ash. Chemosphere 2001, 45, 123-128. [CrossRef]

24. Lima, A.T.; Ottosen, L.M.; Ribeiro, A.B. Assessing fly ash treatment: Remediation and stabilization of heavy metals. J. Environ. Manag. 2012, 95, S110-S115. [CrossRef] [PubMed]

25. Stankowski, S.; Sobolewska, M.; Jaroszewska, A.; Gibczyńska, M. Influence of biomass ash, lime and gypsum fertilization on macro- and microelement contents in the soil and grains of spring wheat. Soil Sci. Ann. 2018, 69, 177-183. [CrossRef]

26. Bakisgan, C.; Dumanli, A.G.; Yürüm, Y. Trace elements in Turkish biomass fuels: Ashes of wheat straw, olive bagasse and hazelnut shell. Fuel 2009, 88, 1842-1851. [CrossRef]

27. Greinert, A. Clays as substances limiting phytotoxic influence of $\mathrm{Pb}, \mathrm{Zn}$ and $\mathrm{Cd}$ in sandy soils. In Contaminated Soil'95; Van Den Brink, W.J., Bosman, R., Arendt, F., Eds.; Springer: Dordrecht, The Netherlands, 1995; Volume 5, pp. 1223-1225. ISBN 978-94-011-0421-0.

28. Greinert, A. Improving the sorption properties of soils as obligatory for maintaining green urban areas in good condition. Soil Sci. Ann. 2009, 60, 75-83.

29. Zha, F.; Liu, S.; Du, Y.; Cui, K. Behavior of expansive soils stabilized with fly ash. Nat. Hazards 2008, 47, 509-523. [CrossRef]

30. Kuo, W.T.; Gao, Z.C. Engineering Properties of Controlled Low-Strength Materials Containing Bottom Ash of Municipal Solid Waste Incinerator and Water Filter Silt. Appl. Sci. 2018, 8, 1377. [CrossRef] 
31. Papandreou, A.D.; Stournaras, C.J.; Panias, D.; Paspaliaris, I. Adsorption of $\mathrm{Pb}(\mathrm{II}), \mathrm{Zn}(\mathrm{II})$ and $\mathrm{Cr}$ (III) on coal fly ash porous pellets. Miner. Eng. 2011, 24, 1495-1501. [CrossRef]

32. Backes, C.A.; Pulford, I.D.; Duncan, H.J. Seasonal Variation of Pyrite Oxidation Rates in Colliery Spoil. Soil Use Manag. 1993, 9, 30-34. [CrossRef]

33. Meyer, G.; Waschkies, C.; Hüttl, R.F. Investigations on pyrite oxidation in mine spoils of the Lusatian lignite mining district. Plant Soil 1999, 213, 137-147. [CrossRef]

34. Drab, M.; Greinert, A. Calcium content in post-mining grounds in the Łęknica Region. Civ. Environ. Eng. Rep. 2010, 4, 46-57.

35. Dung, T.T.T.; Vassilieva, E.; Swennen, R.; Cappuyns, V. Release of Trace Elements from Bottom Ash from Hazardous Waste Incinerators. Recycling 2018, 3, 36. [CrossRef]

36. Yu, Q.; Sawayama, S.; Sugita, S.; Shoya, M.; Isojima, Y. The reaction between rice husk ash and $\mathrm{Ca}(\mathrm{OH})_{2}$ solution and the nature of its product. Cem. Concr. Res. 1999, 29, 37-43. [CrossRef]

37. Martirena, F.; Middendorf, B.; Day, R.L.; Gehrke, M.; Roque, P.; Martinez, L. Rudimentary, low tech incinerators as a means to produce reactive pozzolan out of sugar cane straw. Cem. Concr. Res. 2006, 36, 1056-1061. [CrossRef]

38. Pasupathy, K.; Berndt, M.; Sanjayan, J.; Rajeev, P.; Cheema, D.S. Durability of low-calcium fly ash based geopolymer concrete culvert in a saline environment. Cem. Concr. Res. 2017, 100, 297-310. [CrossRef]

39. Jia, S.; Richardson, I.G. Micro- and nano-structural evolutions in white Portland cement/pulverized fuel ash cement pastes due to deionized-water leaching. Cem. Concr. Res. 2018, 103, 191-203. [CrossRef]

40. Ranjbar, N.; Mehrali, M.; Mehrali, M.; Alengaram, U.J.; Jumaat, M.Z. Graphene nanoplatelet-fly ash based geopolymer composites. Cem. Concr. Res. 2015, 76, 222-231. [CrossRef]

41. Page, A.L.; Miller, R.H.; Keeney, D.R. Methods of Soil Analysis. Part 2. Chemical and Microbiological Methods; American Society of Agronomy/Soil Science Society of America: Madison, WI, USA, 1982; pp. 323-336. ISBN 0-89118-072-9.

42. Toscano, G.; Alfano, V.; Scarfone, A.; Pari, L. Pelleting Vineyard Pruning at Low Cost with a Mobile Technology. Energies 2018, 11, 2477. [CrossRef]

43. Ribbing, C. Environmentally friendly use of non-coal ashes in Sweden. Waste Manag. 2007, 27, 1428-1435. [CrossRef] [PubMed]

44. Smriti, S.; Ram, L.C.; Masto, R.E.; Verma, S.K. A comparative evaluation of minerals and trace elements in the ashes from lignite, coal refuse, and biomass fired power plants. Int. J. Coal Geol. 2011, 87, 112-120. [CrossRef]

45. Karapinar, N.; Donat, R. Adsorption behaviour of $\mathrm{Cu}^{2+}$ and $\mathrm{Cd}^{2+}$ onto natural bentonite. Desalination 2009, 249, 123-129. [CrossRef]

46. Ayala, J.; Fernández, B. A Case Study of Landfill Leachate Using Coal Bottom Ash for the Removal of Cd ${ }^{2+}$, $\mathrm{Zn}^{2+}$ and $\mathrm{Ni}^{2+}$. Metals 2016, 6, 300. [CrossRef]

47. Kabata-Pendias, A.; Pendias, H. Biogeochemia Pierwiastków Śladowych; PWN: Warszawa, Poland, 1999; ISBN 3-01128-23-2.

48. Kabata-Pendias, A.; Pendias, H. Trace Elements in Soils and Plants, 3rd ed.; CRC Press LLC: Boca Raton, FL, USA, 2001.

49. Lis-Krzyścin, A. N Fertilization and Nutrient Status of Geranium Plant Pelargonium x hortium. Acta Agrophys. 2006, 7, 651-661.

50. Grigatti, M.; Giorgioni, M.E.; Ciavatta, C. Compost-based growing media: Influence on growth and nutrient use of bedding plants. Bioresour. Technol. 2007, 98, 3526-3534. [CrossRef] [PubMed]

51. Cregg, B. Conifer nutrition. The Michigan Landscape. Conifer Corner 2005, 9-10, 42-45.

52. Kuang, Y.W.; Wen, D.Z.; Zhou, G.Y.; Liu, S.Z. Distribution of elements in needles of Pinus massoniana (Lamb.) was uneven and affected by needle age. Environ. Pollut. 2007, 145, 146-153. [CrossRef] [PubMed]

(C) 2019 by the authors. Licensee MDPI, Basel, Switzerland. This article is an open access article distributed under the terms and conditions of the Creative Commons Attribution (CC BY) license (http://creativecommons.org/licenses/by/4.0/). 